\title{
Assessment of Effects of Thyrotoxicosis on Gallstone Formation in Rabbits
}

\section{Tavşanlarda Tirotoksikozun Safra Taşı Oluşumu Üzerine Etkilerinin Değerlendirilmesi}

\author{
๑ Yusuf Günay, ๑ Tanju Tütüncü*, ๑ Tuba Öcalan**, ๑ Ayşe Bilgihan***, \\ (1) Gülcan Korkmaz ${ }^{* \star * *}$, (1) Nuri Aydın Kama*****
}

Bülent Ecevit University Faculty of Medicine, Department of General Surgery, Zonguldak, Turkey

*University of Health Sciences, Ankara Numune Training and Research Hospital, Clinic of General Surgery, Ankara, Turkey

**University of Health Sciences, Ankara Numune Training and Research Hospital, Clinic of Pathology, Ankara, Turkey

*** Ufuk University Faculty of Medicine, Department of Biochemistry, Ankara, Turkey

$* * *$ University of Health Sciences, Ankara Numune Training and Research Hospital, Clinic of Biochemistry, Ankara, Turkey

$* * * * *$ Bolu izzet Baysal University Faculty of Medicine, Department of General Surgery, Bolu, Turkey

\section{Abstract}

\begin{abstract}
Aim: The etiopathogenesis of gallstone formation is well known, but only a few studies have investigated the effects of thyrotoxicosis on gallstone formation. In this study, we investigated the contribution of thyrotoxicosis to gallstone formation in rabbits.
\end{abstract}

Methods: Forty-four New Zealand rabbits were used. The rabbits were divided into six groups, with each group receiving a different diet. At the end of seven weeks, all rabbits were sacrificed, blood was collected for analysis, and cholecystectomy was performed.

Results: Serum levels of both free triiodothyronine (FT3) and thyroxine (FT4) were significantly higher in rabbits receiving thyroid hormone $(p<0.001)$. The bile cholesterol saturation index (CSI) in the group receiving only thyroxine hormone was statistically higher than in the control group ( $p=0.014)$. The rabbit group receiving a lithogenic diet and thyroxine hormone had significantly higher myeloperoxidase activities and fibrinogen levels, but lower bile acid levels compared to controls $(p<0.001)$. Focal leukocyte infiltration was noted in rabbits receiving thyroxine hormone, but no significant differences were found in bile calcium levels between the groups ( $p>0.05)$.

Conclusions: Thyrotoxicosis promotes an increase in gallstone formation risk as a result of an increased bile CSI and gallbladder mucosal inflammation.

Keywords: Cholelithiasis, thyrotoxicosis, gallstone, hyperthyroidism, cholesterol
Amaç: Safra taşı oluşumun etiyopatogenezi bilinmesine rağmen, tirotoksikozun safra taşı oluşumu üzerinde etkisini araştıran çok az sayıda çalışma bulunmaktadır. Bu çalışmada tavşanlarda tirotoksikozun safra taşı üzerine etkileri araştııılmışırı.

Yöntemler: Kırk dört adet Yeni Zelanda tipi tavşan kullanıldı. Tavşanlar, altı gruba bölündü ve her grup farklı diyetle beslendi. Çalışmanın 7. haftasında tavşanlar sakrifiye edilerek kan örnekleri alındı ve kolesistektomi yapıldı.

Bulgular: Tiroksin hormonu verilen tavşanlarda serbest T3 ve T4 düzeyleri anlamlı şekilde yüksek bulundu $(p<0,001)$. Kontrol grubu ile karşılaştırılı̆̆ında tiroksin hormonu verilen tavşanlarda safra kolesterol satürasyon indeksi (CSI) anlamlı şekilde yüksek bulundu $(p=0,014)$. Litojenik diyet ile tiroksin hormonu alan tavşanlardaki miyeloperoksidaz ve fibrinojen serum düzeyleri kontrol grubundaki tavşanların düzeylere göre anlamlı şekilde yüsek bulunurken, safra asit düzeyleri istatistiksel olarak düşük bulundu $(p<0,001)$. Tiroksin hormonu alan tavşanlarda safra kesesi mukozasında fokal infiltrason tespit edilirken, gruplar arasında safra serum kalsiyum düzeyleri arasında anlamlı bir fark bulunmadı $(p>0,05)$.

Sonuç: Tirotoksikoz, safra CSI'yı ve mukozal enflamasyonu arttırarak safra taşı oluşumu riskini arttırmaktadır.

Anahtar Sözcükler: Kolelitiaziz, tirotoksikoz, safra taşı, hipertiroidizm, kolesterol

Address for Correspondence/Yazışma Adresi: Yusuf Günay

Bülent Ecevit University Faculty of Medicine, Department of General Surgery, Zonguldak, Turkey

E-mail:drygunay@gmail.com ORCID ID: orcid.org/0000-0002-6518-9997

Received/Geliş Tarihi: 08 October 2018 Accepted/Kabul Tarihi: 07 February 2019 University of Health Sciences Haseki Training and Research Hospital

The Medical Bulletin of Haseki published by Galenos Yayınevi.

OTelif Hakkı 2019 Sağlık Bilimleri Üniversitesi Haseki Eğitim ve Araştırma Hastanesi Haseki Tip Bülteni, Galenos Yayınevi tarafından yayınlanmıştır. 


\section{Introduction}

Almost $10 \%-15 \%$ of the adult population in developed countries have a diagnosis of cholelithiasis $(1,2)$. Bile stones consist of three main elements: 1. cholesterol, 2. bile pigment and 3. calcium salts (3). Gallstones are classified as cholesterol gallstones and pigment gallstones which are subdivided into black and brown pigment gallstones. The most common gallstone type is cholesterol gallstone that constitutes about $70 \%$ of all gallstones (4). The risk factor for cholesterol gallstone are cholesterol supersaturation, nucleation and gallbladder hypomotility $(5,6)$. Other risk factors for cholesterol gallstones include age, gender, genetics, obesity, weight loss, and bowel disease (7). The association between serum lipid levels and gallstone has been reported and studies have shown that cholesterol saturation index (CSI), which is one of the main factors for gallstone formation, was more crucial than cholesterol concentration $(8,9)$. CSI is described as the ratio of measured concentration of cholesterol to the measured concentration of bile salts plus phospholipid (10). A gallstone starts with a nucleus formation, and it has been shown that nucleus formation time was shortened by a lithogenic diet $(4,11)$. There are some additional factors, including mucus, calcium, and transferrin that accelerate gallstone nucleus formation, but some other factors such as bile and fatty acids prevent it $(4,10,11)$.

Although some studies have reported a higher prevalence of both hypothyroidism and subclinical hypothyroidism in gallstone patients, which supports a possible relationship between low thyroxine (T4) levels and gallstone disease (12-14), there are few data regarding the contribution of thyroxicosis to gallstone formation (12).

\section{Methods}

The study was approved by the Ankara Education and Training Hospital Ethics Committee and was registered with a number of 2002/11/002. The study was conducted in accordance with the 1996 Guide for Care and Use of Laboratory Animals.

Forty-four New Zealand rabbits were used in this study. The rabbits were divided into six groups: group 1 (control group)-fed with a standard rabbit diet and water and did not receive any medications, group 2 (lithogenic group)fed with a lithogenic diet consisting of $1 \%$ cholesterol and $0.5 \%$ bile acid and water and group 3 (thyrotoxicosis group) - fed with a standard diet and received $0.5 \mu \mathrm{g} / \mathrm{kg} /$ day L-thyroxine via the oral route, group 4 (thyrotoxicosis and anti-inflammatory group)-fed with a standard diet and received $0.5 \mathrm{\mu g} / \mathrm{kg} / \mathrm{d}$ L-thyroxine with $10 \mathrm{mg} / \mathrm{kg} / \mathrm{d}$ indomethacin via the oral route, group 5 (thyrotoxicosis and ursodeoxycholic acid) - fed with a standard diet and received $0.5 \mu \mathrm{g} / \mathrm{kg} / \mathrm{d}$ L-thyroxine with $50 \mathrm{mg} / \mathrm{kg} / \mathrm{d}$ ursodeoxycholic acid; and group 6 (thyrotoxicosis and alendronate group)-fed with a standard diet and received $0.5 \mathrm{\mu g} / \mathrm{kg} / \mathrm{d}$ L-thyroxine with $2.5 \mathrm{mg} / \mathrm{kg} / \mathrm{d}$ alendronate via the oral route. At the end of seven weeks, all rabbits were sacrificed and blood was obtained for biochemical analysis of serum triiodothyronine (FT3) and FT4, fibrinogen, calcium, cholesterol, and bile acid. A bile sample was collected for analysis of bile calcium, bile acid, and cholesterol levels. Cholecystectomy was performed to obtain samples for assessing tissue myeloperoxidase (MPO) activities and determining inflammation.

\section{Biochemical Analysis}

Thyroid function test: Serum samples obtained from the rabbits were analyzed using an Abbot Architect i2000SR immunoassay analyzer (Abbott Laboratories Diagnostic Division, Abbott Park, USA).

Serum calcium and cholesterol levels: Samples were measured by spectrophotometric analysis using Olympus AU cholesterol OSR 6116 and calcium OSR 6176 (Olympus Diagnostica $\mathrm{GmbH}$, Clare, Ireland).

Fibrinogen levels: Serum samples were evaluated with the photo-optical method using a BCT analyzer (Dade-Behring, Marburg Germany) standard fibrinogen kit (Fibrinogen Kit, Catalog No.886-A Sigma Diagnostics, St. Louis, USA).

Bile cholesterol and acids and calcium: Samples were diluted with distilled water at a 1:400 dilution. Spectrophotometric analysis was performed using Olympus AU analyzer cholesterol OSR 6116, calcium OSR 6176 with bile acid OSR 6279 kits (Olympus Diagnostica $\mathrm{GmbH}$, Clare, Ireland).

Myeloperoxidase: MPO activity was used as a marker for inflammation of the gallbladder. Gallbladder mucosal samples were homogenized with $1 \mathrm{~mL}$ of ice-cold buffer containing $50 \mathrm{mM}$ potassium phosphate $(\mathrm{pH}$ : 7.4) for $1 \mathrm{~min}$. The homogenized samples were sonicated for $20 \mathrm{sec}$ and centrifuged at $1200 \mathrm{rpm}$ for $12 \mathrm{~min}$ at $4^{\circ} \mathrm{C}$. Supernatants were removed after centrifugation and collected in different tubes. MPO activity was assessed by measuring the $\mathrm{H}_{2} \mathrm{O}_{2}$-dependent oxidation of o-dianisidine. One unit of enzyme activity was defined as the amount of MPO present that caused a change in absorbance of 1.0/ min at $410 \mathrm{~nm}$ and $37^{\circ} \mathrm{C}$.

Histopathological evaluation: Gallbladder mucosal inflammation was examined using samples from the gallbladder mucosa that were stained with hematoxylin and eosin and examined under light microscope at 40x magnification. Three pathological scores were developed and described:

1. 0: No infiltration (0 leukocyte/40x);

2. 1: Trace infiltration (4-5 leukocytes/40x);

3. 2: Focal or diffuse infiltration (>10-15 leukocytes/40x). 


\section{Statistical Analysis}

Data were expressed as mean \pm standard deviation. One-Way analysis of variance (ANOVA) was applied to test the differences between the groups. Significant differences between two groups were determined using a post-hoc Tukey test. All statistical analyses were conducted using SPSS software v. 16.0 and a p value of less than 0.05 was considered statistically significant.

\section{Results}

\section{Serum FT3, FT4}

The analysis of serum FT3 level showed statistically significant differences between the groups $(p<0.0001$, Table 1, Figure 1). The Tukey test showed that serum FT3 level was statistically higher in rabbits receiving only thyroid hormone compared to control group $(7.3 \pm 1.1 \mathrm{vs}$ $2.37 \pm 0.74 \mathrm{ng} / \mathrm{mL}, \mathrm{p}<0.001)$, but no statistical differences were noted between group 4, group 5 and group 6 $(6.5 \pm 0.84$ vs $6.95 \pm 1.3 \mathrm{ng} / \mathrm{mL}, p=0.45$ and $6.5 \pm 0.84$ vs $6.7 \pm 1.1 \mathrm{ng} / \mathrm{mL}, \mathrm{p}=0.96$ and $6.95 \pm 1.3$ vs $6.7 \pm 1.1 \mathrm{ng} / \mathrm{mL}$, $p=0.77$, respectively).

The analysis of serum FT4 levels showed that there was statistically significant differences between the groups $(p<0.0001$, Table 1, Figure 1). The Tukey test showed that serum FT4 level was statistically higher in groups 3, 4 and 5 receiving thyroid hormone compared to control group $(1.7 \pm 0.56$ vs $0.5 \pm 0.04 \mathrm{ng} / \mathrm{mL}, p<0.001,1.3 \pm 0.4$ vs $0.5 \pm 0.04 \mathrm{ng} / \mathrm{mL}, \mathrm{p}<0.001$ and $1.1 \pm 0.0 .25$ vs $0.5 \pm 0.04 \mathrm{ng} /$ $\mathrm{mL}, \mathrm{p}=0.006$, respectively), but there was no statistically significant difference between group 6 and control group $(0.95 \pm 0.30$ vs $0.5 \pm 0.04 \mathrm{ng} / \mathrm{mL}, \mathrm{p}=0.80$ ).

\section{Serum Cholesterol, Bile Cholesterol, and Bile Acids} Levels

There was a statistically significant difference in serum cholesterol levels between the groups (Table 1, Figure 2). Post-hoc analysis showed that serum cholesterol levels in lithogenic group were statistically significantly higher than in control group $(710 \pm 98$ vs $108 \pm 34.7 \mathrm{mg} / \mathrm{dL}, \mathrm{p}<0.001)$. Serum cholesterol levels were significantly lower in group 3 than in control group ( $48 \pm 13$ vs $108 \pm 34.7 \mathrm{mg} / \mathrm{dL}$, $\mathrm{p}=0.036)$.

There was a statistically significant difference in bile cholesterol levels between the groups $(p<0.001$, Table 1$)$. The Tukey test showed that bile cholesterol in lithogenic group was statistically significantly higher than in control group ( $215 \pm 69$ vs $56 \pm 25 \mathrm{mg} / \mathrm{dL}, p<0.001)$, but no significant differences were noted between group 3 and group 1 ( $40 \pm 13$ vs $56 \pm 25 \mathrm{mg} / \mathrm{dL}, \mathrm{p}=0.882$ ).

The rabbit group receiving the lithogenic diet had statistically lower bile acid levels than controls $(178 \pm 36.5$ vs $73 \pm 25 \mathrm{mg} / \mathrm{dL}, \mathrm{p}<0.001)$. Group 3 had significantly lower

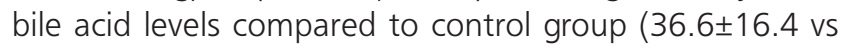
$178 \pm 36.5 \mathrm{mg} / \mathrm{dL} p<0.001$ ).

\begin{tabular}{|c|c|c|c|c|c|c|c|}
\hline Variables & $\begin{array}{l}\text { Groups } 1 \\
\text { (mean } \pm \text { SD) }\end{array}$ & $\begin{array}{l}\text { Groups } 2 \\
\text { (mean } \pm \text { SD) }\end{array}$ & $\begin{array}{l}\text { Groups } 3 \\
\text { (mean } \pm S D)\end{array}$ & $\begin{array}{l}\text { Groups } 4 \\
\text { (mean } \pm \text { SD) }\end{array}$ & $\begin{array}{l}\text { Groups } 5 \\
\text { (mean } \pm \text { SD) }\end{array}$ & $\begin{array}{l}\text { Groups } 6 \\
\text { (mean } \pm \text { SD) }\end{array}$ & $p$ value \\
\hline FT3 (ng/mL) & $2.37 \pm 0.74$ & $2.6 \pm 0.4$ & $7.3 \pm 1.1$ & $6.5 \pm 0.84$ & $6.95 \pm 1.3$ & $6.7 \pm 1.1$ & $p<0.001$ \\
\hline $\mathrm{FT} 4$ (ng/dL) & $0.5 \pm 0.04$ & $0.66 \pm 0.04$ & $1.7 \pm 0.56$ & $1.3 \pm 0.4$ & $1.1 \pm 0.25$ & $0.95 \pm 0.30$ & $p<0.001$ \\
\hline MPO (U/mg) & $0.8 \pm 0.25$ & $1.7 \pm 0.15$ & $1.56 \pm 0.24$ & $0.69 \pm 0.2$ & $1.46 \pm 0.2$ & $1.48 \pm 0.25$ & $p<0.001$ \\
\hline $\begin{array}{l}\text { Fibrinogen } \\
\text { (mg/dL) }\end{array}$ & $1.3 \pm 0.23$ & $2.9 \pm 1.5$ & $3.2 \pm 1.1$ & $0.95 \pm 0.3$ & $2.4 \pm 0.8$ & $2.6 \pm 0.7$ & $p<0.001$ \\
\hline $\begin{array}{l}\text { Serum cholesterol } \\
(\mathrm{mg} / \mathrm{dL})\end{array}$ & $108 \pm 34.7$ & $710 \pm 98$ & $48 \pm 13$ & $49 \pm 22$ & $29 \pm 14$ & $63 \pm 19$ & $p<0.001$ \\
\hline $\begin{array}{l}\text { Bile cholesterol } \\
(\mathrm{mg} / \mathrm{dL})\end{array}$ & $56 \pm 25$ & $215 \pm 69$ & $40 \pm 13$ & $50 \pm 16.5$ & $25.3 \pm 20$ & $96.6 \pm 16.5$ & $p<0.001$ \\
\hline Bile acids (mg/dL) & $178 \pm 36.5$ & $73 \pm 25$ & $36.6 \pm 16.4$ & $40.5 \pm 15$ & $88 \pm 50$ & $30.6 \pm 9.6$ & $p<0.001$ \\
\hline $\begin{array}{l}\text { Cholesterol } \\
\text { saturation index }\end{array}$ & $0.32 \pm 0.15$ & $3.05 \pm 0.87$ & $1.44 \pm 0.61$ & $1.45 \pm 0.8$ & $0.53 \pm 0.73$ & $1.25 \pm 0.64$ & $p<0.001$ \\
\hline $\begin{array}{l}\text { Serum calcium } \\
(\mathrm{mg} / \mathrm{dL})\end{array}$ & $6.6 \pm 0.66$ & $8.4 \pm 0.51$ & $10.2 \pm 1$ & $10.0 \pm 57$ & $9.4 \pm 1$ & $4.4 \pm 0.8$ & $p<0.001$ \\
\hline $\begin{array}{l}\text { Bile calcium } \\
\text { (mg/dL) }\end{array}$ & $82.6 \pm 33$ & $109.3 \pm 51$ & $101 \pm 35$ & $89 \pm 28$ & $100 \pm 25$ & $80 \pm 31$ & $p=0.48$ \\
\hline
\end{tabular}




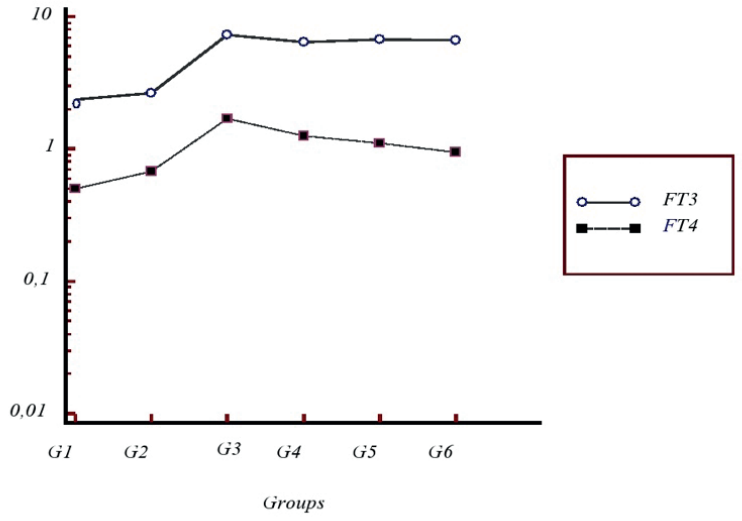

Figure 1. The analysis of serum FT3 and FT4 levels showed that there was significant differences between groups $(p<0.001)$. Serum FT3 and FT4 levels were statistically higher in group 3 compared to group $1(p<0.001$ and $p<0.001)$ and group 2 $(p<0.001$ and FT4: $p<0.001)$

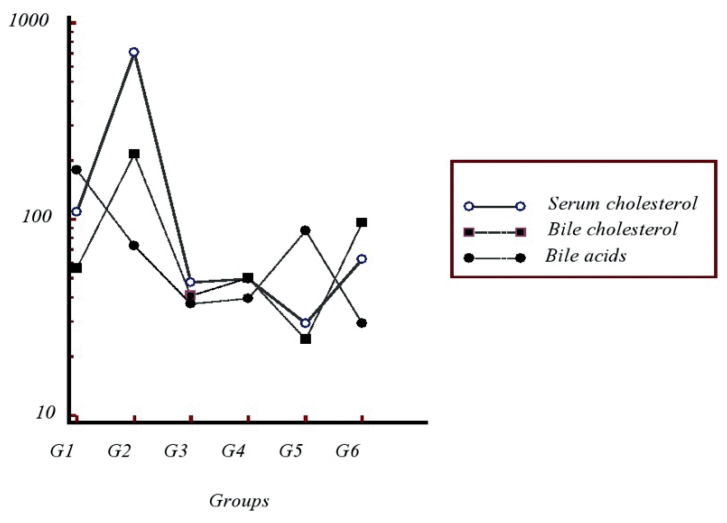

Figure 2. Serum cholesterol levels were statistically different between groups $(p<0.001)$. Serum cholesterol level was statistically higher in group 2 compared to group $1(p<0.001)$, but it was lower in group 2 compared to group 3 ( $p=0.036)$. Bile cholesterol levels were found out to be statistically different among all groups $(p<0.001)$. The group 2 and group 3 had statistically lower bile acid levels compared to the group 1 $(p<0.001, p<0.001)$

\section{Bile CSI}

There was a statistically significant difference in CSI between the groups $(p<0.001)$, (Table 1, Figure 3$)$. The rabbit group receiving lithogenic diet had statistically significantly higher CSI compared to controls $(3.05 \pm 0.87$ vs. $0.32 \pm 0.15, p<0.001)$. The $C S I$ in the group receiving only thyroxine hormone was statistically higher than in control group (1.44 \pm 0.61 vs $0.32 \pm 0.15, p=0.014)$. However, the differences in CSI bile levels between the rabbit group receiving the thyroxine hormone in addition to ursodeoxycholic acid (group 5) and control group were not significant $(0.53 \pm 0.73$ vs $0.32 \pm 0.15 \mathrm{p}=0.985)$.

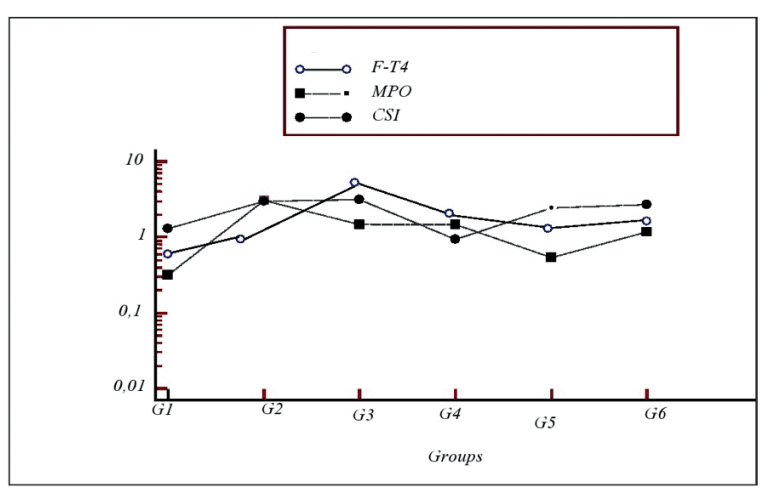

Figure 3. The bile cholesterol saturation index (CSI) differed among groups and the diferrence was statistically important $(p<0.001)$. The group 2 had statistically higher CSI compared to group $1 \quad(p<0.001)$. Myeloperoxidase (MPO) level from gallbladder tissue was statistically different among all groups $(p<0.001)$. The group 2 and group 3 had statistically higher MPO levels compared to group $1(p<0.001$ and $p<0.001)$. MPO activities and CSI compared based on FT4 levels

\section{MPO Activities and Fibrinogen Levels}

There was a statistically significant difference in MPO activities in the gallbladder tissue between the groups $(p<0.001$, Table 1, Figure 3$)$. The MPO activity in the rabbit groups receiving lithogenic diet (group 2) and only thyroxine hormone (group 3) was statistically higher than in control group ( $1.7 \pm 0.15$ vs $0.8 \pm 0.25, p<0.001$ and $1.56 \pm 0.24$ vs $0.8 \pm 0.25, p<0.001$, respectively). No statistically significant difference was found between groups of rabbits receiving lithogenic diet versus thyroxine hormone $(1.7 \pm 0.15$ vs $1.56 \pm 0.24, p=0.731)$. The rabbit group receiving both thyroxine hormone and indomethacin had statistically significantly lower MPO activities compared to both groups of rabbits receiving lithogenic diet and those of receiving thyroxine hormone only $(0.69 \pm 0.2$ vs $1.7 \pm 0.15, p<0.001$ and $0.69 \pm 0.2$ vs $1.56 \pm 0.24, p<0.001$, respectively), but no differences were found compared to control group $(0.69 \pm 0.2$ vs $0.8 \pm 0.25, p=0.885)$.

A statistically significant difference was found in serum fibrinogen level between the groups $(p<0.001$, Table 1). The lithogenic diet and thyroxine only groups had significantly higher fibrinogen levels compared to that in control group $(2.9 \pm 1.5$ vs $1.3 \pm 0.23 \mathrm{mg} / \mathrm{dL}, \mathrm{p}=0.008$ and $3.2 \pm 1.1$ vs $1.3 \pm 0.23 \mathrm{mg} / \mathrm{dL}, p<0.001$, respectively), but no differences were found between lithogenic diet and thyroxine only groups $(2.9 \pm 1.5$ vs $3.2 \pm 1.0 \mathrm{mg} /$ $\mathrm{dL}, \mathrm{p}=0.990)$. The rabbit group receiving both thyroxine hormone and indomethacin had statistically lower fibrinogen levels compared to rabbit groups receiving lithogenic diet and thyroxine hormone only $(0.95 \pm 0.3 \mathrm{vs}$ $2.9 \pm 1.5 \mathrm{mg} / \mathrm{dL}, \mathrm{p}=0.001$ and $0.95 \pm 0.3$ vs $3.2 \pm 1.0 \mathrm{mg} /$ 
$d L, p<0.001$, respectively). No statistically significant differences were found between control group and the rabbit group receiving both thyroxine hormone and indomethacin $(1.3 \pm 0.23$ vs $0.95 \pm 0.3 \mathrm{mg} / \mathrm{dL}, \mathrm{p}=0.933)$.

\section{Serum and Bile Calcium Levels}

There were statistically significant differences in serum calcium levels between the groups ( $p<0.001$, Table 1$)$. The rabbit group receiving thyroxine hormone had statistically higher serum calcium levels compared to control group $(10.2 \pm 1.0$ vs $6.6 \pm 0.66 \mathrm{mg} / \mathrm{dL}, \mathrm{p}<0.001)$. The rabbit group receiving both thyroxine hormone and alendronate had lower serum calcium levels compared to control and thyroxine hormone only groups $(4.4 \pm 0.8$ vs $6.6 \pm 0.66 \mathrm{mg} /$ $\mathrm{dL}, \mathrm{p}=0.036$ and $4.4 \pm 0.8$ vs $10.2 \pm 1.0 \mathrm{mg} / \mathrm{dL}, \mathrm{p}<0.001$, respectively). No significant differences were found in bile calcium levels between the groups ( $p=0.487)$ (Table 1).

\section{Histopathological Examination}

When comparing control group with lithogenic diet group, focal leukocyte infiltration in the gallbladder mucosa was observed in rabbits receiving lithogenic diet. Focal leukocyte infiltration was also noted in rabbits receiving thyroxine hormone, but no infiltration was found in rabbits receiving thyroxine hormone in addition to antiinflammatory agents.

\section{Discussion}

The effect of hypothyroidism on gallstone formation is well known (12), but information related to the effects of thyrotoxicosis on gallstone formation is scarce in the literature. In this study, we found an increased risk for gallstone formation in animals with thyrotoxicosis. We further investigated the underlying mechanisms of thyrotoxicosis contribution to gallstone formation and discovered unique thyrotoxicosis mechanisms in gallstone formation. The effects of hyrotoxicosis on gallstone formation were investigated by examining the effects of thyrotoxicosis on bile CSI, mucosal inflammation, serum fibrinogen, and bile calcium levels.

There have been several studies investigating the etiopathogenesis of gallstone and risk factors for gallstone formation (15). As with most common diseases, gallstones are believed to be multifactorial influenced by both genetic and environmental factors $(16,17)$. Studies have shown that the most important factors in the etiopathogenesis are biliary system motor dysfunction, gallbladder mucosal inflammation, and increased CSI $(9,18,5)$.

Bile cholesterol disturbances are essential for gallstone formation (19). Studies have shown that CSI was more important than cholesterol levels in cholelithiasis formation $(5,20)$. These findings were attributed to an increase in cholesterol and bile salt deficiency (10), and our results are consistent with those findings. We found that the bile cholesterol levels were lower even in the rabbit groups receiving thyroxine hormones because the bile acid levels were much lower in these groups. The CSI was statistically higher in rabbits receiving thyroxine. As confirmed in this study, it has been shown that thyroid hormones decreases bile acid formation (12,21-23). It has been shown that thyrotoxicosis-induced cholesterol gallstones are formed through over-expression of the hepatic nuclear receptor genes, Lxr $\alpha$ and Rxr, which are major components of the cholesterol metabolism pathway $(12,24,25)$. Furthermore, thyroid hormone has been shown to stimulate secretion of cholesterol into the bile (13). Therefore, thyroid hormones and thyroid hormone receptor beta must play a part in bile cholesterol homeostasis. Cholesterol supersaturation occurs due to either excessive cholesterol or insufficient bile salts (26). This study showed that high CSI occurs in thyrotoxicosis as a result of lower bile salt concentrations.

It has been shown that experimental animals fed with lithogenic diet had increased MPO activity which is a well known marker of inflammation (13). Fibrinogen is an acute-phase reactant and is elevated in chronic low-grade inflammation (15). Gallbladder mucosal absorption deteriorates in case of mucosal inflammation that increases bile concentration and causes lithogenic bile $(27,28)$. We revealed that thyroid hormone can act as a pathophysiological regulator of inflammation generation in gallbladder mucosa. This was confirmed by higher MPO and fibrinogen levels in rabbits receiving thyroxine hormone compared to that in controls. The same result was seen with lithogenic diet. Moreover, MPO activities and fibrinogen levels in rabbits receiving both thyroxine hormone and indomethacin showed that thyroxine hormone-induced inflammation was reversed by anti-inflammatory agents. It has been showed that patients with gallstones have an abnormal gallbladder mucins and glycoproteins (15). Abnormal gallbladder mucins and glycoproteins increase bile saturation that could further increase thegallstone formation (5). The gallbladder mucosal inflammation that was shown in this study revealed that thyrotoxicosis promotes cholesterol associated gallstone formation in rabbits.

Calcium has an important role in the formation of gallbladder stones (29). Almost all pigment and cholesterol gallstone nuclei consist of calcium bilirubinate $(29,30)$. Hypercalcemia induced by thyrotoxicosis has been reported in the literature (31). This study showed that thyrotoxicosis increases serum calcium levels that may promote gallstone formation. It is most likely due to bone resorption that is responsible for this effect since it was reversed by alendronate $(32,33)$. 


\section{Conclusion}

This study showed that thyrotoxicosis promotes gallbladder stone formation by increasing bile CSI and gallbladder mucosal inflammation. Further studies investigating the effects of thyrotoxicosis on biliary system function are warranted.

Acknowledgment: We would like to thank Selda Seçkin MD, Ali Güçtekin MD, Ahmet istanbullu MD, and Ümmühani Özel MD, PhD for helps and sharing their pearls of wisdom with us during the course of this research, and we would also like to thank Kamil Değer for his great assistance in the laboratory. This study was not financially supported by any institution or company.

\section{Authorship Contributions}

Surgical and Medical Practices: Y.G., G.K. Concept: Y.G., T.T., N.A.K. Design: Y.G., T.T. Data Collection or Processing: Y.G., T.Ö., A.B., G.K. Analysis or Interpretation: Y.G., T.T., T.Ö., A.B., G.K., N.A.K. Literature Search: Y.G. Writing: Y.G., T.T.

Conflict of Interest: No conflict of interest was declared by the authors.

Financial Disclosure: The authors declared that this study received no financial support.

\section{References}

1. Acalovschi M. Gallstones in patients with liver cirrhosis: incidence, etiology, clinical and therapeutical aspects. World J Gastroenterol 2014;20:7277-85.

2. Wilkins T, Agabin E, Varghese J, Talukder A. Gallbladder Dysfunction: Cholecystitis, Choledocholithiasis, Cholangitis, and Biliary Dyskinesia. Prim Care 2017;44:575-97.

3. Krawczyk M, Stokes CS, Lammert F. Genetics and treatment of bile duct stones: new approaches. Curr Opin Gastroenterol 2013;29:329-35.

4. Koivusalo Al, Pakarinen MP, Sittiwet C, et al. Cholesterol, noncholesterol sterols and bile acids in paediatric gallstones. Dig Liver Dis 2010;42:61-6.

5. Raghavendra CK, Srinivasan K. Influence of dietary tender cluster beans (Cyamopsis tetragonoloba) on biliary proteins, bile acid synthesis and cholesterol crystal growth in rat bile. Steroids $2015 ; 94: 21-30$.

6. Lambou-Gianoukos S, Heller SJ. Lithogenesis and bile metabolism. Surg Clin North Am 2008;88:1175-94.

7. Stinton LM, Shaffer EA. Epidemiology of gallbladder disease: cholelithiasis and cancer. Gut Liver 2012;6:172-87.

8. Xu G, Li Y, Jiang X, Chen H. CAV1 Prevents Gallbladder Cholesterol Crystallization by Regulating Biosynthesis and Transport of Bile Salts. J Cell Biochem 2016;117:2118-27.

9. Pasternak A, Bugajska J, Szura M, et al. Biliary Polyunsaturated Fatty Acids and Telocytes in Gallstone Disease. Cell Transplant 2017;26:125-33.
10. Lee EJ, Kim MH, Kim YR, Park JW, ParkWJ. Proteasome inhibition protects against diet-induced gallstone formationthrough modulation of cholesterol and bile acid homeostasis. Int J Mol Med 2018;41:1715-23.

11. Smelt AH. Triglycerides and gallstone formation. Clin Chim Acta 2010;411:1625-31.

12. Wang $Y, Y u$ X, Zhao QZ, et al. Thyroid dysfunction, either hyper or hypothyroidism, promotes gallstoneformation by different mechanisms. J Zhejiang Univ Sci B 2016;17:515-25.

13. Bonde $Y$, Plosch T, Kuipers F, Angelin B, Rudling M. Stimulation of murine biliary cholesterol secretion by thyroid hormone is dependent on a functional ABCG5/G8 complex. Hepatology 2012;56:1828-37.

14. Pedrelli M, Pramfalk C, Parini P. Thyroid hormones and thyroid hormone receptors: effects of thyromimetics on reverse cholesterol transport. World J Gastroenterol 2010;16:595864.

15. Ridker PM. From C-reactive protein to interleukin-6 to interleukin-1: moving upstream to identify novel targets for atheroprotection. Circ Res 2016;118:145-56.

16. Di Ciaula A, Wang DQ, Portincasa P. An update on the pathogenesis of cholesterol gallstone disease. Curr Opin Gastroenterol 2017;34:71-80.

17. Katsika D, Grjibovski A, Einarsson C, Lammert F, Lichtenstein $P$, Marschall HU. Genetic and environmental influences on symptomatic gallstone disease: a Swedish study of 43,141 twin pairs. Hepatology 2005;41:1138-43.

18. Wang HH, Portincasa P, Wang DQ. Update on the Molecular Mechanisms Underlying the Effect of Cholecystokinin and Cholecystokinin-1 Receptor on the Formation of Cholesterol Gallstones. Curr Med Chem 2017;4:456-61.

19. Portincasa P, Wang DQ. Intestinal absorption, hepatic synthesis, and biliary secretion of cholesterol: where are we for cholesterol gallstone formation? Hepatology 2012;55:1313-6.

20. Di Ciaula A, Garruti G, Frühbeck G, et al. The Role Of Diet In The Pathogenesis Of Cholesterol Gallstones. Curr Med Chem 2017;11:124-8.

21. Song $Y, X u C$, Shao $S$, et al. Thyroid-stimulating hormone regulates hepatic bile acid homeostasis via SREBP-2/HNF-4 $\alpha$ / CYP7A1 axis. J Hepatol 2015;62:1171-9.

22. Ockenga J, Valentini L, Schuetz T, et al. Plasma bile acids are associated with energy expenditure and thyroid function in humans. J Clin Endocrinol Metab 2012;97:535-42.

23. Patti M-E, Houten SM, Bianco AC, et al. Serum bile acids are higher in humans with prior gastric bypass: potential contribution to improved glucose and lipid metabolism. Obesity 2009;17:1671-7.

24. Hashimoto K, Mori M. Crosstalk of thyroid hormone receptor and liver $X$ receptor in lipid metabolism and beyond. Endocr J 2011;58:921-30.

25. Liu M, Liu C, Chen H, et al. Prevention of cholesterol gallstone disease by schaftoside in lithogenic diet-induced C57BL/6 mouse model. Eur J Pharmacol 2017;815:1-9.

26. Venneman NG, van Erpecum KJ. Pathogenesis of gallstones. 
Gastroenterol. Clin. North Am 2009;39:171-83.

27. Rege RV. Inflammatory cytokines alter human gallbladder epithelial cell absorption/secretion. J Gastrointest Surg 2000;4:185-92.

28. Lavoie B, Nausch B, Zane EA, Leonard MR. Disruption of gallbladder smooth muscle function is an early feature in the development of cholesterol gallstone disease. Neurogastroenterol Motil 2012;24:313-24.

29. Cariati A. Gallstone Classification in Western Countries. Indian J Surg 2015;77:376-80.

30. Yu JK, Pan H, Huang SM, et al. Calcium content of different compositions of gallstones and pathogenesis of calcium carbonate gallstones. Asian J Surg 2013;36:26-35.

31. Chen K, Xie Y, Zhao L, Mo Z. Hyperthyroidism-associated hypercalcemic crisis: A case report and review of the literature. Medicine (Baltimore) 2017;96:6017.

32. Bigi A, Boanini E. Calcium Phosphates as Delivery Systems for Bisphosphonates. J Funct Biomater 2018;9:1-18.

33. Boanini E, Torricelli P, Gazzano M, Fini M, Bigi A. The effect of alendronate doped calcium phosphates on bone cells activity. Bone 2012;51:944-52. 